\title{
Habitat, redescription and distribution of Latrodectus geometricus in Uruguay (Araneae: Theridiidae)
}

\author{
Miguel Simón ${ }^{1,3}$, María de Fátima da Rocha Dias ${ }^{1}$, Carolina Jorge ${ }^{1}$, Manuel Castro ${ }^{1}$, \\ Marcelo Alves Dias ${ }^{1,2}$ \& Álvaro Laborda \\ ${ }^{1}$ Sección Entomología, Facultad de Ciencias, Universidad de la República, \\ Iguá 4225, CP 11400, Montevideo, Uruguay \\ ${ }^{2}$ Centro de Ecologia e Conservação Animal - ECOA, Instituto de Ciências Biológicas - ICB, \\ Universidade Católica do Salvador - UCSal, Av. Prof. Pinto de Aguiar, 2589, \\ Pituaçu, CEP 40710-000, Salvador, BA, Brasil \\ ${ }^{3}$ Corresponding author: Miguel Simó, e-mail: simo@fcien.edu.uy
}

SIMÓ, M., DIAS, M.F.R., JORGE, C., CASTRO, M., DIAS, M.A. \& LABORDA, A. Habitat, redescription and distribution of Latrodectus geometricus in Uruguay (Araneae: Theridiidae). Biota Neotrop. 13(1): http:// www.biotaneotropica.org.br/v13n1/en/abstract?short-communication+bn02813012013

Abstract: This study provides the first accurate records of Latrodectus geometricus C. L. Koch, 1841 for Uruguay and extends the known distribution of this species to the Southeastern region of South America. Data and figures of the genitalic morphology for the recognition of the species and natural history in this country are indicated. In Uruguay L. geometricus was mainly restricted to urban areas at the west of this country and it is associated with locations with high human activity.

Keywords: brown widow, spider, invasive alien species, Latrodectinae.

SIMÓ, M., DIAS, M.F.R., JORGE, C., CASTRO, M., DIAS, M.A. \& LABORDA, A. Hábitat, redescripción y distribución de Latrodectus geometricus en Uruguay (Araneae: Theridiidae). Biota Neotrop. 13(1): http:// www.biotaneotropica.org.br/v13n1/pt/abstract?short-communication+bn02813012013

Resumen: Este estudio reporta los primeros registros precisos de Latrodectus geometricus C. L. Koch, 1841 en Uruguay y extiende la distribución conocida de esta especie para la región sureste de Sudamérica. Datos y figuras de las estructuras genitales para el reconocimiento de la especie e historia natural en este país son indicados. En Uruguay L. geometricus se encuentra principalmente restringida a áreas urbanas del oeste de este país y asociada a sitios con elevada actividad humana.

Palabras clave: viuda marrón, araña, especie invasora, Latrodectinae. 


\section{Introduction}

The brown widow spider, Latrodectus geometricus C. L. Koch, 1841 , is a medium spider of the family Theridiidae that belongs to a species group of medical interest due to its neurotoxic venom effect on human health (McCrone 1964, Fundação... 2001). Although envenomations by L. geometricus are considered less severe than those of other species of the genus (Vetter \& Isbister 2008), the cases reported vary from local to systemic damages (Cardoso et al. 2003, Goddard et al. 2008, Kiriakos et al. 2008, Almeida et al. 2009). This species has an affinity for human structures and residential buildings (Bayram et al. 2008, Brazil et al. 2009, Vetter et al. 2012) where it constructs a web of irregular shape. This web is characterized by the presence of a retreat located at the top with a central disc and gumfoot lines with fluff mass and balls of glue (Eberhard et al. 2008) The round egg sacs show very characteristic protuberances of silk spikes (Vincent et al. 2008). When this spider is disturbed, it will go to a retreat located in the top of the web or exhibit a long thanatosis. These behaviors, clearly not aggressive, contribute to the consideration that $L$. geometricus is a Latrodectus species that is less dangerous to humans (McCrone 1964, Brown et al. 2008).

Probably native from Africa, L. geometricus has expanded its range around the world mainly in the last century as a consequence of globalization (Garb et al. 2004), to becoming in a cosmopolitan spider (Brown et al. 2008, Platnick 2013). Certainly human transport and trade were the most important ways of dispersal (Garb et al. 2004). Its adaptation to live in synanthropic habitats has also promoted its expansion to new sites worldwide. From the 80s until today it has been reported in Costa Rica, Hawaii, Australia, Japan, southern California (USA), Indonesia, Papua, New Guinea, Israel, India, Pakistán and Turkey (Garb et al. 2004, Eberhard et al. 2008, Vincent et al. 2008, Bayram et al. 2008, Brown et al. 2008). In South America this species has been reported from Argentina, Brazil, Chile, Colombia, Guyana, Perú, Paraguay and Venezuela (Levi 1959, 1967, Abalos 1980, Taucare-Ríos 2011). In Uruguay the species was briefly reported for the first time in an arachnological field guide (Aisenberg et al. 2011), but many aspects about the distribution and natural history of this species in Uruguay were still unclear. In this paper we provide: $\mathrm{i}$, a diagnosis and a brief description of $L$. geometricus with data for the recognition of both sexes; ii, the first precise records with a distributional map; iii, data and comments about the habitats and dispersal of this invasive species in Uruguay.

\section{Materials and Methods}

We revised the theridid specimens deposited in the arachnological collections of the Museo Nacional de Historia Natural (MNHN, M. Simó) and Facultad de Ciencias, Universidad de la República (FCE, M. Simó), both from Montevideo. These institutions conserve the specimens of spiders collected in the last fifty years in a great number of natural and modified habitats of Uruguay. Furthermore we searched spiders in sampling field trips carried out in many cities across the North, Center and South of the country between 2009 to 2011.These specimens were collected by hand, preserved in ethanol (70\%) and deposited in FCE. The identification of the exemplars was done according to Levi (1967). Based on the georeferential data of the records, we elaborated a distribution map of the species using the program DIVA-GIS 7.4 (Hijmans et al. 2005). Measurements are in millimeters.

\section{Results}

\section{Latrodectus geometricus Koch, 1841}

Latrodectus geometricus. C. L. Koch, 1841: 117, figure 684 (Type from Colombia, South America).
Latrodectus geometricus: Bayram, Danyşman, Yiğit, Kunt \& Sankac 2008:99, figures 2-4; Aisenberg, Ghione \& Toscano-Gadea 2011:121; Taucare-Ríos 2011:40, Figure 1.

More information about the synonymic list, see Platnick (2013).

Diagnosis. Adults specimens of the brown widow Latrodectus geometricus differs from the black widow Latrodectus mirabilis Holmberg 1876 (for this species see Abalos 1980, Figures 1-13), the other Uruguayan species of the genus, by the body coloration, morphology of the copulatory organs and its adaptation to live in urban habitats. Females can be distinguished by the dorsal brown coloration of the abdomen with spots (Figure 1a) and by the presence of lateral and posterior lips in the epigynum (Figure 1b). Males can
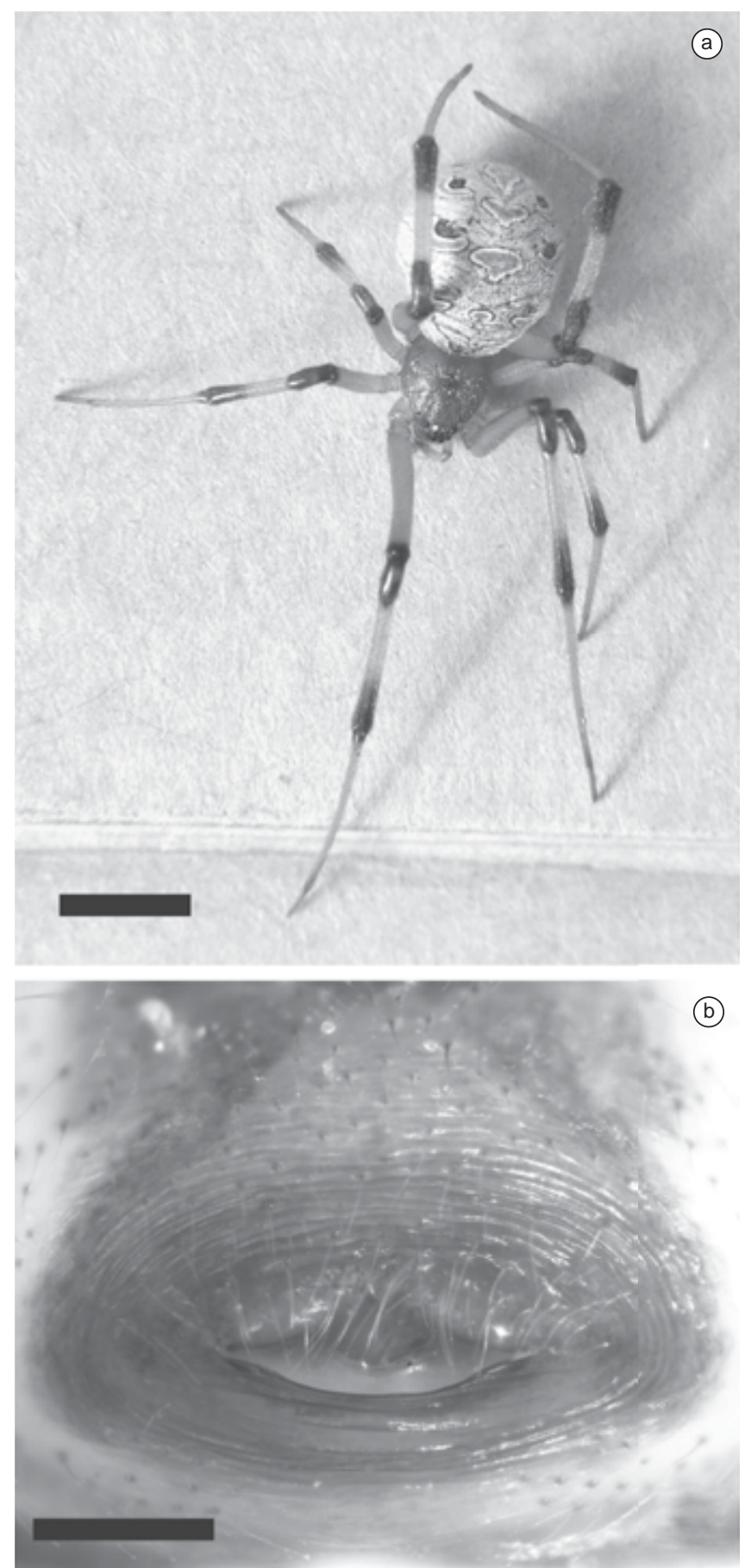

Figure 1. Latrodectus geometricus, female: a) dorsal view. Scale: $5 \mathrm{~mm}$; b) epigynum, ventral view. Scale: $0.25 \mathrm{~mm}$. 

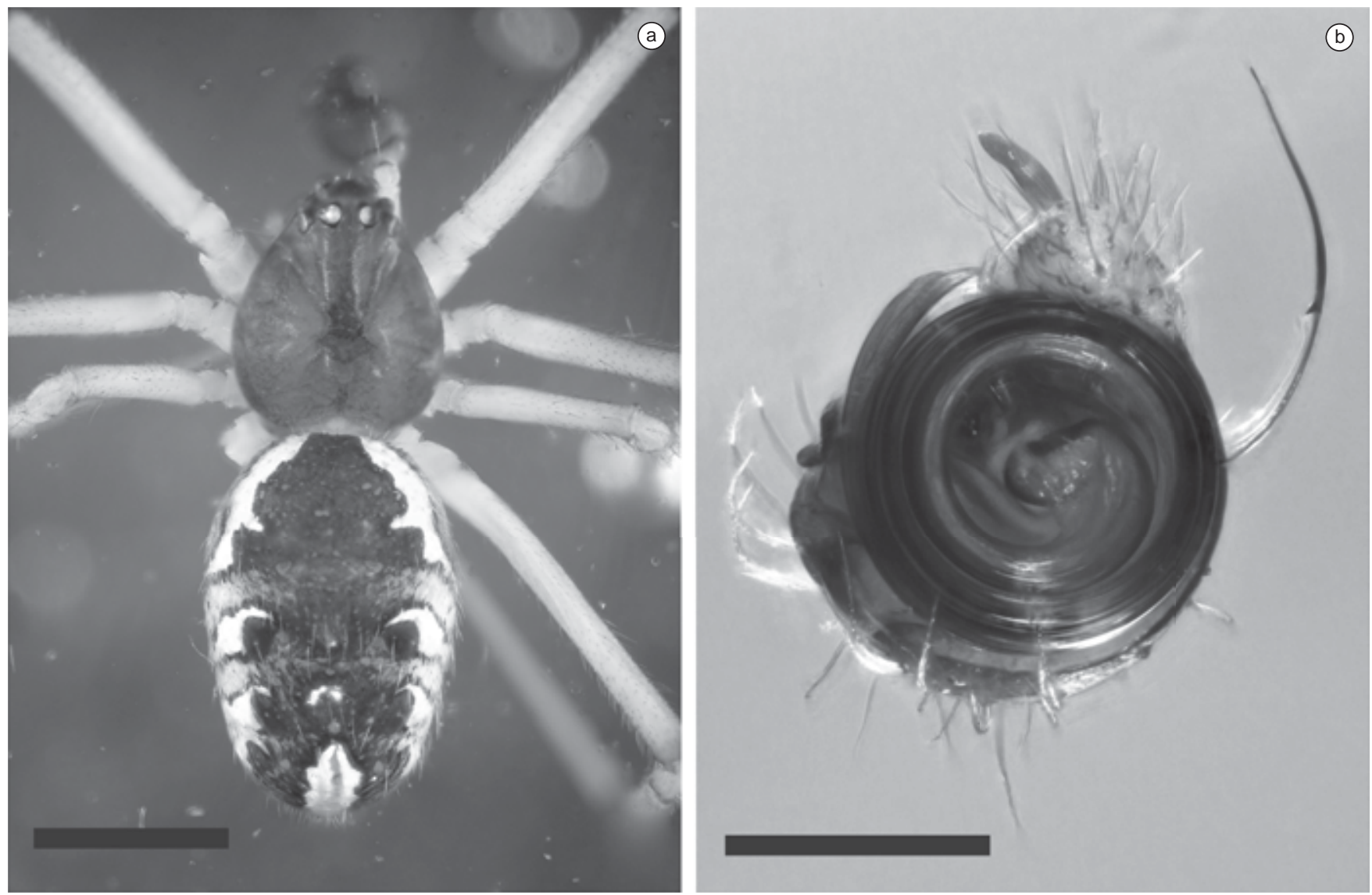

Figure 2. Latrodectus geometricus, male: a) dorsal view. Scale: $1 \mathrm{~mm}$; b) bulb, ventral view. Scale: $0.25 \mathrm{~mm}$.

be recognized by the dorsal longitudinal dark band of the abdomen and by the embolus with four loops (Figure 2b).

Brief description. Female (Figure 1a). The coloration of the dorsal abdomen varies from light brown to dark with spots that vary from dark orange to white. In ventral view, it presents a longitudinal orange area. The epigynum presents sclerotized lips situated posteriorly on each side (Figure 1b). The vulva shows copulatory ducts coiled, laterally projecting and spermatechae dumb-bell-shaped, with the posterior end closer together (Levi 1967, Figure 58). Variation (5 females): body length: 7.7-9.1; carapace width: 2.5-2.9; femur I: 5.6-6.5.

Male (Figure 2a): The carapace is darker than that of the corresponding female and the dorsal abdomen presents a longitudinal dark band with lateral white spots. Ventral abdomen as in the female. The bulb presents a long and coiled embolus with four loops (Figure 2b). Variation (5 males): body length: 2.7-3.2; carapace width: 0.9-1.1; femur I: 2.4-2.9.

Material examined. We examined a total of 63 specimens of this species, 43 females, 14 males and 6 immatures (I). Uruguay, Artigas, Artigas city, February 1993, 1ㅇ, A. Diestre (FCE 2958); 27-V-2010, 1 , L. F. García (FCE 2938); 31-V-2010, 1 으, L. F. García (FCE 5824); 31-V-2010, 10, 2 +, L. F. García (FCE 2939); Paysandú, Constancia, 26-V-2012, 1 ㅇ, 1I, A. Laborda (FCE 2959); Paysandú city, 22-IV-2011, $3 \hat{\jmath}, 6$ ㅇ, A. Laborda (FCE 2323); 29-III-2010, $2 \hat{\jmath}$, 4, A. Laborda (FCE 2931); 08-V-2010, 20 , 4 9 , 3I, A. Laborda (FCE

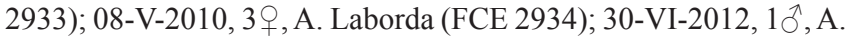
Laborda (FCE 5820); 09-V-2010, 4ㅇ, A. Laborda (FCE 5823); 30-III2010, 1 + , A. Laborda (FCE 5825); 16-IX-2010, 1 §ิ, 3 ㅇ, M. Simó \& A. Laborda (FCE 2936); 03-I-2007, 10̄, 3 + , A. Laborda (FCE 2937); 29-III-2010, 19, A. Laborda (FCE 2960); Río Negro, Nuevo Berlín,

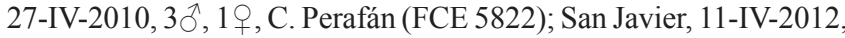
1 , , A. Laborda (FCE 2955); Young, 15-VII-2012, 1 , 1 I. Laborda (FCE 2997); Salto, Salto city, Artigas square, 17-IX-2010, 4, 1J, M. Simó, C. Jorge \& A. Laborda (FCE 2932); Soriano, Route 14, Arroyo Cololó, In containment barriers, 24-IV-2010, 1 中, M. Simó \& A. Laborda (FCE 2935).

Distribution. The specimens proceeded from urban localities in the provinces of Artigas, Paysandú, Salto, Río Negro and Soriano, except one that was registered to one side of a route. The distribution map (Figure 3) shows that this species is found from the northwest to southwest of the country.

Habitat and natural history. Most individuals were observed in urban environments outside houses, at gardens and parks (Figure 4a), as well as at containment barriers located on both sides of the roads (Figure 4b). The most common sites where the spiders constructed their webs were at corners of windows, in wall crevices and under park benches. The females mainly constructed their webs between two meters high to near the ground with a retreat situated at the top of the web with a central area from where gumfoot lines are projected to the substrate (Figure 4c). Thanatosis was observed when spiders were disturbed (Figure 4d).

\section{Discussion}

The urban habitats occupied by Latrodectus geometricus in Uruguay and the association of this species with synanthropic habitats are similar to that indicated to from other cities as windows frames and wall crevices in New Orleans and California in U.S.A. (Brown et al. 2008, Vetter et al. 2012) or under park benches in Yokohama, Japan (Ono 1995). At the same time the web architecture is similar to that described by Eberhard et al. (2008). The presence on the routes of 
Simó, M. et al.

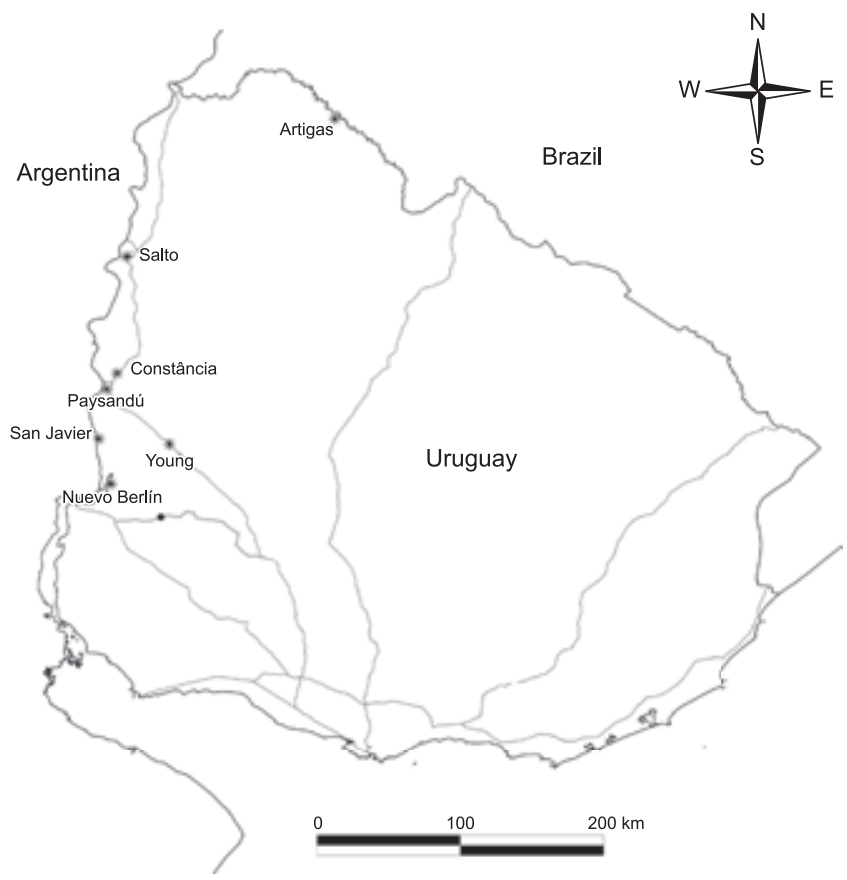

Figure 3. Records of Latrodectus geometricus in Uruguay: urban localities (asterisc) and route (black circle). Grey lines: main routes of the country.

L. geometricus in Uruguay would be associated with its ability to disperse through human transport pathways, as has been mentioned for other countries (Brown et al. 2008, Taucare-Ríos 2011). The find of this species only in Western Uruguay, the fact that it was not found in the field trips carried out to the East, North and South of this country and the lack of captures of this species before 1993 in its actual distributional range in Uruguay, give a strong evidence that its presence is a result of a recent invasion. In this sense the species was reported to the neighboring countries, Brazil and Argentine, several decades ago. Brown et al. (2008) reported that the presence of L. geomerticus in New Orleans, U.S.A. was due to the accidental transport by vehicles, ornamental plants and building materials. The traffic of trade between countries was suggested by Taucare-Ríos (2011) as the way of invasion of this species to Chile. In the last decades of twentieth century new terrestrial connections along the Uruguay River were built and the transport of trade, vehicles and people were highly increased between these countries. All these considerations support the assumption that $L$. geometricus is in a great expansion of its distributional range, as was reported for others parts of the world (Garb et al. 2004). Recently, Vetter et al. (2012) reported the frequent presence of the brown widow spider in urban areas of southern California, USA, and the prevalence of this species in cities, around buildings, in greater numbers than the native black widow, Latrodectus hesperus Chamberlain \& Ivie 1935, the latter being more common in natural and agricultural areas. Similarly, in Uruguay L. geometricus prevails in urban habitats in contrast to the native $L$. mirabilis which lives in grasslands under stones or in agricultural crops. Although L. geometricus shows non-aggressive behavior and human envenomation by brown widow spiders are less severe than those caused by other Latrodectus species (Brown et al. 2008, Vetter \& Isbister 2008, Vetter et al. 2012), its presence in urban habitats and its potential dispersal to other parts of Uruguay represents a new agent of health and pest control interest in this country. The high dependence of $L$. geometricus to live associated with humans shows the potential condition of this species as a good bioindicator to detect environmental disturbance in natural habitats.
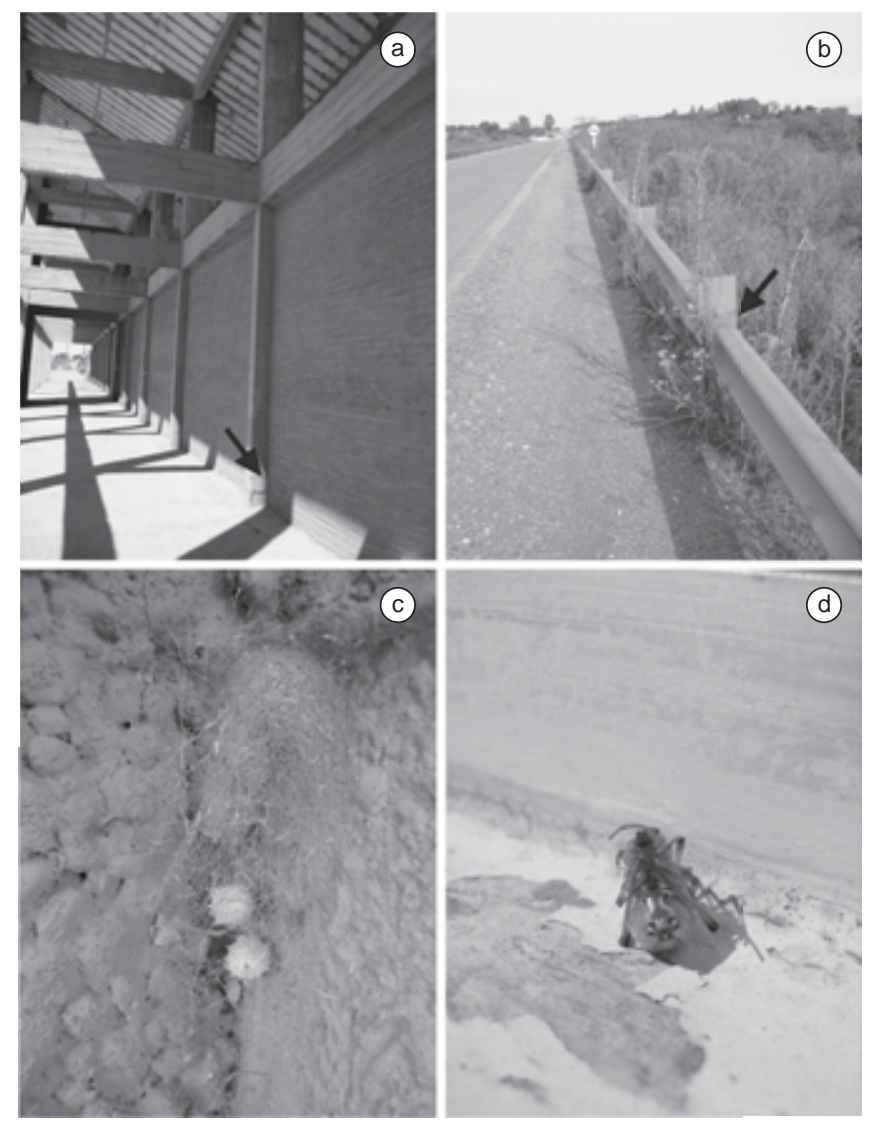

Figure 4. Latrodectus geometricus in Uruguay: a) arrow indicating a wall crevice, one site where individuals of this species can be easily found; b) arrow indicating a containment barrier at the side of road, another habitat of the species; c) the web, showing the retreat and two egg sacs; d) specimen exhibiting thanatosis.

\section{Acknowledgements}

To Anita Aisenberg for her comments and for improving the English version of the manuscript. We thank José Carlos Guerrero for his help with the map edition.

\section{References}

ABALOS, J.W. 1980. Las arañas del género Latrodectus en la Argentina. Obra Centen. Mus. La Plata. 6:29-51.

AISENBERG, A., GHIONE, S. \& TOSCANO-GADEA, C. 2011. Guía de arácnidos del Uruguay. Ediciones de la Fuga, Montevideo. PMCid:3025377.

ALMEIDA, R.A.M.B., FERREIRA JUNIOR, R.S., CHAVES, C.R. \& BARRAVIERA, B. 2009. Envenomation caused by Latrodectus geometricus in São Paulo state, Brazil: A case report. J. Venom. Anim. Toxins Incl. Trop. Dis. 15(3):562-571. http://dx.doi.org/10.1590/S167891992009000300016

BAYRAM, A., DANISMAN, T., YIGIT, N., KUNT, K.B. \& SANKAC, A. 2008. A brown widow spider new for the Turkish araneo-fauna: Latrodectus geometricus C. L. Koch, 1841 (Araneae; Theridiidae). Turk. J. Arachnol. 1(1):98-103.

BRAZIL, T.K., PINTO-LEITE, C.M., ALMEIDA-SILVA, L.M., LIRADA-SILVA, R.M. \& BRESCOVIT, A.D. 2009. Aranhas de importância médica do Estado da Bahía, Brazil. Gaz. Méd. Bahia. 79(Supl.1):32-37.

BROWN, K.S., NECAISE, J.S. \& GODDARD, J. 2008. Additions to the known U.S. distribution of Latrodectus geometricus (Araneae: Theridiidae). J. Med. Ent. 45(5):959-962. http://dx.doi.org/10.1603/00222585(2008)45[959:ATTKUD]2.0.CO;2 
CARDOSO, J.L.C., BRESCOVIT, A.D. \& HADDAD, J.R.V. 2003. Clinical aspects of human envenoming caused by Lactrodectus geometricus (Theridiidae) in S. Paulo. J. Venom. Anim. Toxins Incl. Trop. Dis. 9(2):418.

EBERHARD, W.G., BARRANTES, G. \& MADRIGAL-BRENES, R. 2008. Vestiges of an orb-weaving ancestor? The "biogenetic law" and ontogenetic changes in the webs and building behavior of the black widow spider Latrodectus geometricus (Araneae, Theridiidae). Ethol. Ecol. Evol. 20(3):211-244. http://dx.doi.org/10.1080/08927014.2008.9522523

FUNDAÇÃO NACIONAL DE SAÚDE - FUNASA. 2001. Manual de Diagnóstico e Tratamento de Acidentes por Animais Peçonhentos. Ministério da Saúde, Brasilia.

GARB, J.E., GONZÁlEZ, A. \& GILlESPIE, R.G. 2004. The black widow spider genus Latrodectus (Araneae: Theridiidae): phylogeny, biogeography, and invasion history. Mol. Phyl. Evol. 31(3):1127-1142. http://dx.doi.org/10.1016/j.ympev.2003.10.012

GODDARD, J., UPSHAW, S., HELD, D. \& JOHNNSON, K. 2008. Severe Reaction from Envenomation by the Brown Widow Spider, Latrodectus geometricus (Araneae: Theridiidae). So. Med. J. 101(12):1269-1270.

HIJMANS, R.J., GUARINO, L., JARVIS, A., O’BRIEN, R., MATHUR, P., BUSSINK, C., CRUZ, M., BARRANTES, I. \& ROJAS, E. 2005. DIVAGIS. version 7.4. http://www.diva-gis.org (último acesso em 22/01/2010).

KIRIAKOS, D., NÚÑEZ, P., YASMELY, P., MARIANNE GARCÍA, M. MEDINA, J. \& DE SOUSA, L. 2008. First case of human latrodectism in Venezuela. Rev. Soc. Bras. Med. Trop. 41(2):202-204. http://dx.doi. org/10.1590/S0037-86822008000200015
KOCH, C.L. 1841. Die Arachniden. Nürnberg, Achter Band:1-207.

LEVI, H.W. 1959. The spider genus Latrodectus (Araneae: Theridiidae). Trans. Am. Microsc. Soc. 78(1):7-43. http://dx.doi.org/10.2307/3223799

LEVI, H.W. 1967. Cosmopolitan and pantropical species of theridiid spiders (Araneae: Theridiidae). Pac. Ins. 9(2):175-186.

McCRONE, J.D. 1964. Comparative lethality of several Latrodectus venoms. Toxicon 2:201-203. http://dx.doi.org/10.1016/0041-0101(64)90023-6

PLATNICK, N.I. 2013. The world spider catalog. version 12.5. http://research. amnh.org/iz/spiders/catalog/ (último acesso em 12/07/2012.

TAUCARE-RÍOS, A.O. 2011. Primer registro de la viuda marrón, Latrodectus geometricus (Araneae: Theridiidae) en el norte de Chile. Rev. Chi. Ent. 36:39-42.

VETTER, R.S. \& ISBISTER, G.K. 2008. Medical aspects of spider bites. Annu. Rev. Ent. 53:409-429. http://dx.doi.org/10.1146/annurev. ento.53.103106.093503

VETTER, R.S., VINCENT, L.S., DANIELSEN, D.W.R., REINKER, K.I., CLARKE, D.E., ITNYRE, A.A., KABASHIMA, J.N. \& RUST, M.K. 2012. The prevalence of brown widow and black widow spiders (Araneae: Theridiidae) in urban southern California. J. Med. Ent. 49(4):947-951. http://dx.doi.org/10.1603/ME11285

VINCENT, L.S., VETTER, R.S., WRENN, W.J., KEMPF, J.K. \& BERRIAN, J.E. 2008. The brown widow spider Latrodectus geometricus C. L. Koch, 1841, in southern California. Pan Pacific Ent. 84(4):344-349. http://dx.doi.org/10.3956/2008-07.1 